\title{
KURIKULUM BERBASIS KOMPETENSI (Konsep Dasar dan Implementasi)
}

\begin{abstract}
M. Rifai *
Abstract

In effort of the nation surival, a society need a set of educations which are then termed as competence so as to be proffesional, competitive and merit. The basic competence has become the substance of success in live and living. The breakdown of the nation's economy, education, culture and also monetary affairs is not due to the lack of the government power, rather a lack of the basic competence possessed by the political actors, which needs to be questioned. Unfortunately, the prosperity of Indonesian nature can not bring Indonesia to become the master in our own nation, but it does them poverty due to live under pressure of other nation. It has been caused by the lack of the basic competence of our nation in managing, preserving, utilizing the nation's prosperity.
\end{abstract}

Key words: Education, Competence, Proffesional

\begin{abstract}
Abstrak
Guna bertahan untuk hidup atau mempertahankan kehidupan demi kelangsungan kelompok bangsa (warga masyarakatnya), diperlukan seperangkat pendidikan yang biasa disebut kompetensi (kompetensi dasar) agar bangsa Indonesia bisa menjadi sekelompok bangsa yang profesional, kompetitif, dan unggul. Kompetensi dasar adalah ruh dari kesuksesan dalam berkarya. Terpuruknya suatu bangsa baik dari aspek ekonomi, budaya, pendidikan, dan moneter bukan karena ketidakmampuan pemerintah, tetapi justru kompetensi dasar yang dimiliki penyelenggara negara itu sendiri dipertanyakan. Sangat disayangkan keluasan bumi pertiwi dari sabang sampai merauke, kekayaan alam yang berlimpah, kesuburan tanah yang bisa menghasilkan apapun tanaman yang disemai pasti berbuah, itu tidak bisa membawa bangsa Indonesia menjadi tuan rumah di negeri sendiri, tetapi justru sebaliknya menjadi kuli di negeri sendiri yang akibatnya melahirkan kemiskinan, kebodohan, dan bangsa yang selalu hidup dibawah telunjuk bangsa lain, karena itu semua tidak adanya kompetensi dasar yang dimiliki bangsa kita untuk mengelola, menjaga, mengambil manfaat yang besar dari kekayaan alam yang
\end{abstract}

* M. Rifai adalah Dosen PGSD IKIP PGRI Madiun dan Kandidat Doktor Ilmu-Ilmu Sosial Universitas Merdeka Malang 
ada, serta ketidakmampuannya menjaga kelestarian peninggalan ibu pertiwi.

Kata Kunci: Pendidikan, Kompetensi, Professional

\section{A. PENDAhUluan}

Undang-Undang Nomor 20 Tahun 2003 tentang Sistem Pendidikan Nasional menyatakan guru adalah pendidik profesional dengan tugas utama mendidik, mengajar, membimbing mengarahkan, melatih, menilai, dan mengevaluasi peserta didik pada pendidikan anak usia dini jalur pendidikan formal, pendidikan dasar, dan pendidikan menengah. Dosen adalah pendidik profesional dan ilmuan yang bekerja pada satuan pendidikan tinggi dengan tugas utama mentrasformasikan, mengembangkan, dan menyebarluaskan ilmu pengetahuan, teknologi, dan seni melalui pendidikan, penelitian, dan pengabdian kepada masyarakat. Guru besar atau profesor yang selanjutnya disebut profesor adalah jabatan fungsional tertinggi bagi dosen yang masih mengajar di lingkungan satuan pendidikan tinggi.

Profesional adalah pekerjaan atau kegiatan yang dilakukan oleh seseorang dan menjadi sumber penghasilan kehidupan yang memerlukan keahlian, kemahiran, atau kecakapan yang memenuhi standar mutu atau norma tertentu serta memerlukan pendidikan profesi. Penyelenggara pendidikan adalah pemerintah, pemerintah daerah, atau masyarakat yang menyelenggarakan pendidikan pada jalur pendidikan formal. Satuan pendidikan adalah kelompok layanan pendidikan yang menyelenggarakan pendidikan pada jalur pendidikan formal dalam setiap jenjang dan jenis pendidikan. Perjanjian kerja atau kesepakatan kerja bersama adalah perjanjian tertulis antara guru atau dosen dengan penyelenggara pendidikan atau satuan pendidikan yang memuat syaratsyarat kerja serta hak dan kewajiban para pihak dengan prinsip kesetaraan dan kesejawatan berdasarkan peraturan perundang-undangan.

Pemutusan hubungan kerja atau pemberhentian kerja adalah pengakhiran perjanjian kerja atau kesepakatan kerja bersama guru atau dosen karena sesuatu hal yang mengakibatkan berakhirnya hak dan kewajiban antara guru atau dosen dan penyelenggara pendidikan atau satuan pendidikan sesuai dengan peraturan perundang-undangan. Kualifikasi akademik adalah ijazah jenjang pendidikan akademik yang harus di miliki oleh guru atau dosen sesuai dengan jenis, jenjang, dan satuan pendidikan formal ditempat penugasan.

Kompetensi adalah seperangkat pengetahuan, keterampilan, dan perilaku yang harus dimiliki, dihayati, dan dikuasai oleh guru atau dosen dalam melaksanakan tugas keprofesionalan. Sertifikasi adalah proses pemberian sertifikat pendidik untuk guru dan dosen. Sertifikat pendidikan adalah bukti formal sebagai pengakuan yang diberikan kepada guru dan dosen sebagai tenaga professional. Organisasi profesi guru adalah perkumpulan yang berbadan hukum yang didirikan dan diurus oleh guru untuk mngembangkan profesionalitas guru.

Lembaga pendidikan tenaga pendidikan adalah perguruan tinggi yang di beri tugas oleh pemerintah untuk menyelenggarakan program pengadaan guru pada pendidikan anak usia dini jalur pendidikan formal, pendidikan dasar, dan / 
atau pendidikan menengah serta untuk menyelenggarakan dan mengembangkan ilmu pendidikan dan non kependidikan. Gaji adalah hak yang di terima oleh guru atau dosen atas pekerjaannya dari penyelenggara pendidikan atau satuan pendidikan dalam bentuk finansial secara berkala sesuai dengan peraturan perundang undangan. Penghasilan adalah hak yang diterima oleh guru atau dosen dalam bentuk finansial sebagai imbalan melaksanakan tugas keprofesionalan yang ditetapkan dengan prinsip penghargaan atas dasar prestasi dan mencerminkan martabat guru atau dosen sebagai pendidik professional.

Tulisan ini dirancang sebagai bahan bagi para guru, pendidik, tokoh dan pengamat pendidikan untuk memahami secara garis besar apa dan bagaimana konsep dan implementasi Kurikulum Berbasis Kompetensi (KBK). Sesuai judulnya, maka hal-hal yang dikaji bersifat umum, dimaksudkan sebagai pengantar atau memberikan bekal awal dalam mempelajari KBK (kendati pun penulis sangat memahami bahwa para guru, kalangan pendidik, tokoh dan pengamat pendidikan sudah tidak asing, bahkan seringkali mendapatkan materi pembelajaran tentang KBK). Dalam rangka memenuhi aturan yang diberlakukan Menteri Pendidikan Nasional (Mendiknas), sejumlah sekolah dan perguruan tinggi menyatakan memberlakukan KBK bagi siswa / mahasiswanya. Tentu saja (semestinya) pemberlakukan KBK tersebut diikuti dengan pembaharuan dalam banyak hal sebagai implikasinya, semisal pembaharuan pada: lingkungan belajar, strategi pembelajaran, teknik pembelajaran, bahan belajar, dan media belajar.

Persoalan klasik di sejumlah sekolah adalah pemberlakuan KBK acap halnya ditandai oleh satu hal utama, yaitu perubahan nama-nama bidang studi dan perubahan buku ajar. Perubahan lain sebagai penyempurna, bahkan semestinya menjadi "menu paket" atas pemberlakuan KBK, sampai saat ini belum dilakukan secara sempurna oleh sejumlah sekolah / perguruan tinggi (tanpa mengabaikan bahwa disejumlah sekolah / perguruan tinggi tertentu di tanah air, pemberlakuan KBK nyaris sempurna). Penulis berharap tulisan ini menjadi salah satu bahan masukan bagi para guru, kalangan pendidik, dan pengamat pendidikan, dan bagi kita semua, agar kemudian terdorong untuk belajar dan belajar terus tentang apa dan bagaimana KBK, sehingga memberikan konstribusi positif bagi pelaksanaan tugas para guru / pendidik sebagai tenaga fungsional kependidikan di masingmasing bidang studi yang dibina.

\section{B. PEMBAHASAN}

1. Konsep Kurikulum

Kurikulum dalam arti sempit dimaknai sebagai kumpulan berbagai mata pelajaran / mata kuliah yang diberikan kepada peserta didik melalui kegiatan yang dinamakan proses pembelajaran. Kerr dan Kelly berpendapat seiring perkembangan ilmu pegetahuan, khususnya sosio-teknologi, maka kurikulum diartikan secara lebih luas sebagai keseluruhan proses pembelajaran yang direncanakan dan dibimbing di sekolah / kampus, baik yang dilaksanakan di dalam kelompok atau secara individual di dalam atau di luar sekolah / kampus (Kuartolo, 2002). Dalam pengertian ini tercakup di dalamnya sejumlah aktivitas pembelajaran di antara subyek didik dalam melakukan trasnformasi pengetahuan, keterampilan, dengan menggunakan berbagai pendekatan. 
Sementara itu Tyler mengemukakan inti dari kurikulum (Kuartolo, 2002) adalah jawaban secara menyeluruh terhadap beberapa pertanyaan, yakni:

a. Tujuan dan maksud apa yang hendak dicapai melalui proses pembelajaran yang akan diselenggarakan?

b. Kesempatan belajar apa yang lebih dipilih sehingga terjadi perubahan tingkah laku sesuai dengan yang diharapkan?

c. Bagaimana unsur-unsur belajar disusun?

d. Bagaimana penilaian untuk mengetahui hasil pembelajaran?

Jika keempat pertanyaan tersebut telah terjawab, itulah sesungguhnya yang disebut sebagai kurikulum. Namun demikian, konsep kurikulum sebagai urutan sejumlah bidang studi / matakuliah tetap menjadi dasar yang substansial dalam menyusun desain kurikulum. Hanya saja, tidak boleh terjebak untuk memahami kurikulum, sebatas dalam arti sempit saja. Pendidikan mengenal adanya lima tataran kurikulum, seperti yang diilustrasikan pada Gambar 1.

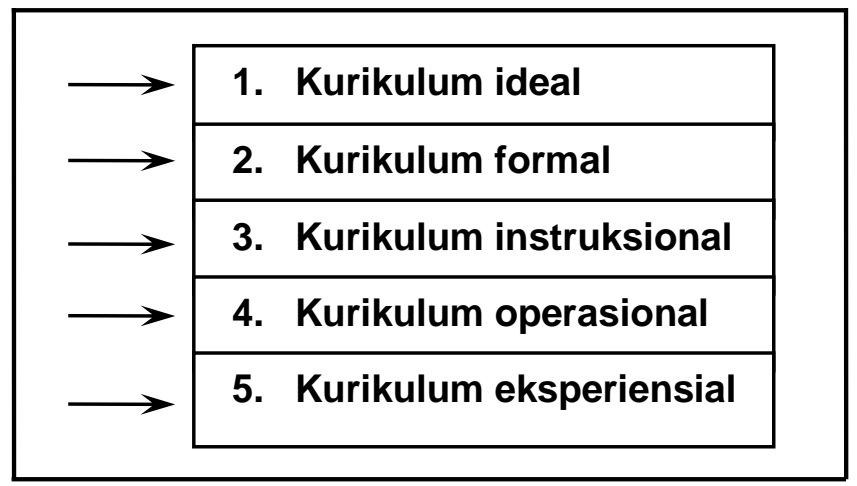

Gambar 1 Lima Tataran Kurikulum

Kurikulum ideal mencakup segala sesuatu yang dianggap penting, sangat luas dan agung, yang ingin dicapai melalui proses pembelajaran. Kurikulum ideal ini kemudian dikonstruk menjadi kurikulum formal dalam bentuk dokumen resmi kurikulum yang diterbitkan oleh Departemen Pendidikan Nasional. Tataran berikutnya adalah kurikulum instruksional yang merupakan terjemahan dari kurikulum formal menjadi seperangkat lesson plans. Pada tataran inilah guru / dosen berperan sebagai pengembang kurikulum di tingkat kelas. Selanjutnya, perwujudan obyektif kurikulum instruksional dalam bentuk kegiatan pembelajaran merupakan wujud kurikulum operasional. Wujud kurikulum operasional adalah apa yang dilakukan siswa / mahasiswa, apa yang dilakukan guru / dosen, dan sebagaimana bentuk interaksi pembelajaran itu. Interaksi guru-siswa / dosenmahasiswa inilah yang akan membuahkan kurikulum eksperiensial berupa makna pengalaman belajar oleh siswa / mahasiswa. Makna yang dibangun siswa / mahasiswa melalui pengalaman belajarnya inilah konstruksi pengetahuan dan kecakapan terjadi, yang membuahkan dampak pada perubahan cara berfikir dan bertindak.

Pada tahapan ini rancangan strategi pembelajaran memegang peranan penting. Oleh karena itu, sesungguhnya tercapainya kehendak yang terkandung 
dalam kurikulum formal amat tergantung pada peran guru/dosen. Berapa kalipun kurikulum formal diperbaharui tidak akan membawa dampak pembaharuan apaapa tanpa kesetiaan guru/dosen dalam menerjemahkan kurikulum formal ke dalam kurikulum eksperiensial.

\section{Konsep Kompetensi}

Istilah kompetensi (competence) sering disandingkan, bahkan acap disamakan dengan kinerja (performance) dan keterampilan (skill). Ketiga istilah ini memang berhubungan erat secara timbal balik, namun berbeda dimensi dan konsepnya. Kompetensi berdimensi batiniah, tidak kasat mata (tidak terindra), dan mentalitas atau abstrak sifatnya, karena berurusan dengan kewenangan atau kekuasaan untuk memahami dan melakukan sesuatu. Sedangkan kinerja dan keterampilan, berdimensi lahiriah, kasat mata (terindra) dan konatif (psikomotoris, teknis) atau konkret, karena berhubungan dengan tindak atau laku untuk memahami dan melakukan sesuatu. Kompetensi selalu terwujud dalam kinerja dan keterampilan. Namun kinerja dan keterampilan tidak selalu, malah tak pernah merupakan cermin atau wujud seluruh kompetensi (yang dimiliki seseorang), melainkan merupakan cermin atau wujud dari sebagaian kompetensi yang dimiliki seesorang.

Dengan kata lain, kinerja dan keterampilan seseorang tidak mencerminkan atau merupakan wujud dari seluruh kompetensi. Ini berarti bahwa kinerja dan keterampilan dapat bertransformasi menjadi kompetensi, dan sebaliknya kompetensi dapat bertransformasi menjadi kinerja dan keterampilan. Berangkat dari pola pikir inilah maka dapat disimpulkan:

a. Kompetensi adalah kekuasaan, keberdayaan, kesanggupan seseorang (yang didasari oleh sikap dan nilai tertentu) dalam memahami dan melakukan sesuatu secara fungsional demi memenuhi kepentingan, kebutuhan, dan tujuan tertentu;

b. Kinerja adalah penampilan, tindak laku, perbuatan seseorang (yang didasari oleh sikap dan nilai tertentu) dalam memahami dan melakukan sesuatu demi memenuhi kepentingan, kebutuhan, dan tujuan tertentu;

c. Keterampilan adalah kemahiran, kecakapan, kecekatan teknis seseorang (yang didasari oleh sikap dan nilai tertentu) dalam mengerjakan, melaksanakan, dan menyelesaikan sesuatu demi memenuhi kepentingan, kebutuhan, dan tujuan tertentu.

Berdasarkan konsep tersebut dapat diketahui bahwa pada dasarnya kompetensi lebih bersifat mentalis dan sosiopsikologis dari pada vokasional, meskipun sikap vokasional juga terkandung dalam kompetensi. Sementara kinerja lebih bersifat konatif dan sosiopsikologis dengan kandungan sifat vokasional yang sangat kuat. Baik kompetensi, kinerja, maupun keterampilan mempunyai hubungan timbal balik, sebagai contoh: kompetensi dapat dikenali melalui kinerja dan keterampilan.

Berangkat dari sejumlah konsep tersebut dapat dimengerti kalau kemudian Depdiknas (2003) mendefinisikan kompetensi sebagai pegetahuan, keterampilan, sikap, dan nilai-nilai yang digunakan oleh seseorang untuk berpikir, bertindak 
(memahami dan melakukan sesuatu). Kompetensi ini dapat dikenali melalui sejumlah hasil belajar dan indikatornya dapat diukur dan diamati, misalnya melalui kinerja dan keterampilan. Hal senada dikemukakan oleh Matec (2001) yang mendefinisikan kompetensi sebagai kesatuan dan kepaduan sejumlah pengetahuan, keterampilan dan nilai-nilai yang diharapkan dapat dikuasai oleh pembelajar yang termanifestasi ke dalam sejumlah kinerja dan kegiatan.

Kedua definisi tersebut memasukkan kinerja dan keterampilan sebagai unsur kompetensi, yang dipadu dengan kualitas sosiopsikologis (mentalis), yaitu sikap dasar nilai-nilai. Berdasarkan dua definisi ini dapat diketahui bahwa:

a. Isi kompetensi berupa kesatuan pengetahuan, keterampilan, sikap, dan nilainilai yang fungsional;

b. Fungsi kompetensi sebagai berfikir dan bertindak atau memahami dan melakukan sesuatu;

c. Menguasai kompetensi berarti mampu, sanggup, dan bisa memahami dan melakukan sesuatu;

d. Mengenali kompetensi seseorang bisa melalui hasil belajar dengan indikator yang dapat diukur dan diamati;

e. Kebutuhan, kepentingan, dan tujuan menguasai kompetensi berupa dapat bekerja, mendapatkan pekerjaan, melanjutkan studi, dan bisa belajar sepanjang hayat.

Atas dasar paparan ini dapat ditegaskan bahwa kompetensi tidak selalu berurusan dengan vokasionalitas dan kekaryaan, tetapi juga intelektualitas, sosialitas, dan karakter. Gambar 2 dapat memperjelas bagaimana wujud kompetensi dalam diri seseorang, yang diadaptasi dari Earnest (2001). Berdasarkan jenjangnya yang semi-hierarkis dapat dipilah sekurang-kurangnya menjadi lima jenjang, yakni:

a. Kompetensi lintas kurikulum adalah kesatuan jumlah pengetahuan, kesanggupan, kecakapan, sikap dan nilai untuk hidup, bekerja, melanjutkan studi, dan belajar sepanjang hayat yang harus dikuasai atau dimiliki siswa/mahasiswa melalui pengalaman belajar;

b. Kompetensi lulusan / tamatan adalah kesatuan jumlah pengetahuan, kesanggupan, kecakapan, sikap dan nilai yang secara fungsional dapat untuk hidup dan belajar yang harus dikuasai dan harus dicapai oleh tamatan jenjang pendidikan tertentu;

c. Kompetensi mata pelajaran (subject matter) adalah kesatuan jumlah pengetahuan, kesanggupan, kecakapan, sikap dan nilai yang berkenaan dengan mata pelajaran / mata perkuliahan tertentu yang harus dikuasai dan dimiliki oleh siswa / mahasiswa, untuk hidup, bekerja, melanjutkan studi, dan belajar sepanjang hayat;

d. Kompetensi bahan kajian adalah kesatuan utuh sejumlah bahan kajian dalam mata pelajaran / mata perkuliahan tertentu secara fungsional dapat digunakan untuk memahami dan melakukan sesuatu yang harus dimiliki dan dicapai oleh siswa / mahasiswa;

e. Kompetensi dasar adalah deskripsi sejumlah pengetahuan, kesanggupan, kecakapan, sikap dan nilai dasar yang berkenaan dengan bahan kajian dalam 
mata pelajaran / mata perkuliahan tertentu yang secara funsional dapat digunakan untuk memahami dan melakukan sesuatu oleh siswa / mahasiswa, misalnya untuk hidup sehari-hari, bekerja, melanjutkan studi, dan belajar.

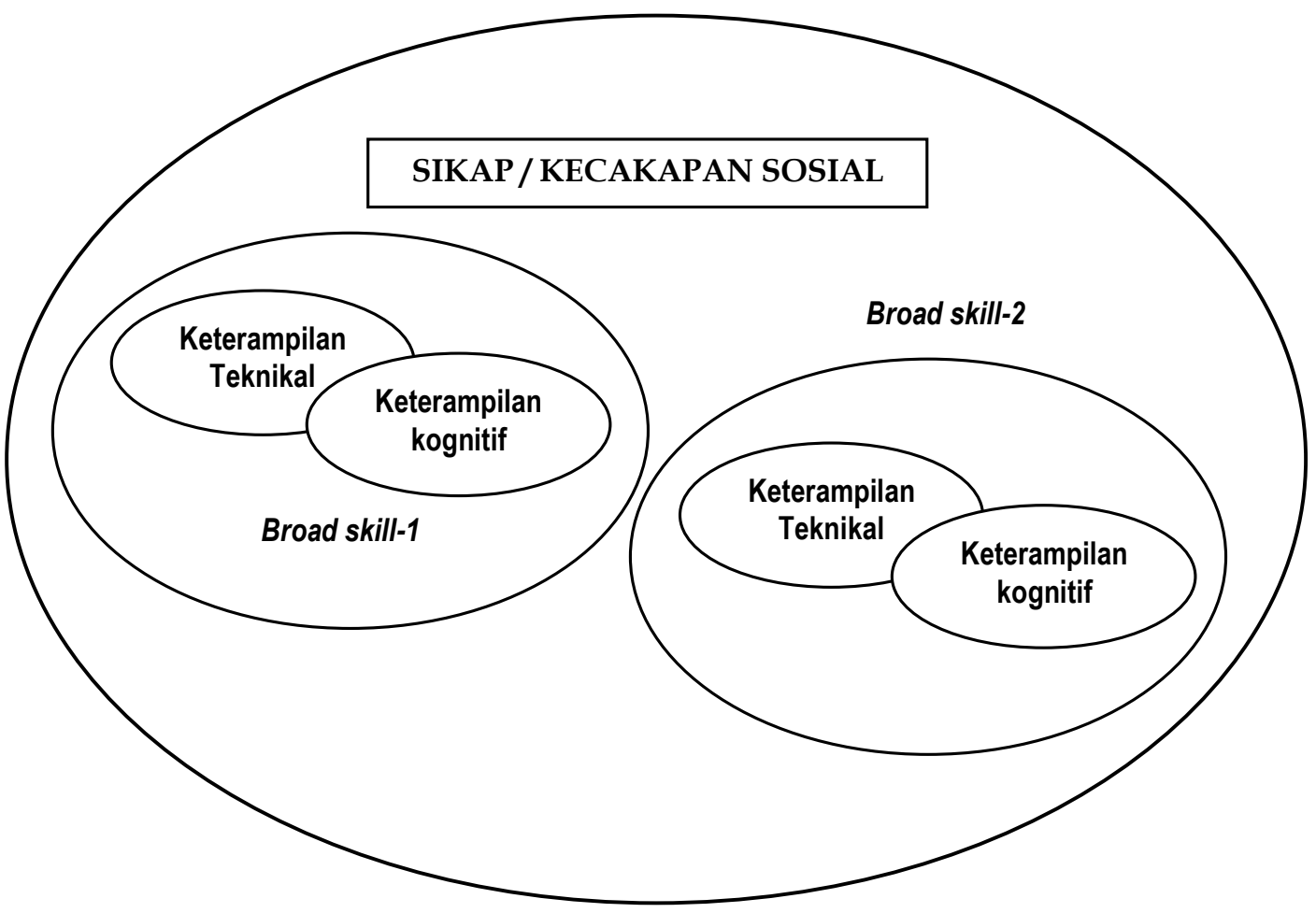

\section{Gambar 2 Wujud Kompetensi}

\section{Apa dan Bagaimana Kurikulum Berbasis Kompetensi?}

Cukup banyak hal yang melatarbelakangi lahirnya KBK, diantaranya adalah: (1) lahirnya konsep tentang kecerdasan ganda (multiple intelligence); (2) tuntutan publik akan peningkatan kemampuan dunia pendidikan untuk mengikuti (beradaptasi) dengan perubahan yang terjadi pada dunia pekerjaan; (3) kecenderungan dunia untuk segera memasuki abad pengetahuan; dan (4) konsep tentang empat pilar belajar versi Unesco, dan sejumlah variabel lain yang juga berpengaruh signifikan terhadap lahir dan diberlakukannya KBK.

Pembahasan tulisan ini hanya akan memilih satu variabel yang melatarbelakangi lahirnya KBK ialah empat pilar belajar versi Unesco. Oleh karena itu, hal-hal yang dibahas dalam bagian ini meliputi: (1) latar belakang KBK, yakni empat pilar belajar versi Unesco; (2) konsep dasar KBK; (3) implementasi KBK versi Departeman Pendidikan Nasional; dan (4) implementasi pemberlakuan KBK.

\section{a. Empat Pilar Belajar Versi Unesco}

Pembaharuan kurikulum nasional (yang kemudian terkenal dengan KBK) merupakan respons terhadap hasil kerja Komisi Internasional tentang Pendidikan untuk Abad XXI. Komisi ini ditugasi Unesco untuk melakukan kajian masa depan 
tentang berbagai kecenderungan, termasuk kecenderungan perubahan jenis pekerjaan, pekerjaan yang akan muncul dan yang akan hilang, akibat revolusi pengetahuan, dan bagaimana pendidikan harus direncanakan sekarang. Komisi ini merekomendasikan bahwa jika pendidikan ingin berhasil melaksanakan tugastugasnya, maka pendidikan hendaknya dibangun disekitar empat jenis belajar yang fundamental sifatnya, yang di sepanjang hayat seseorang, dapat dikatakan sebagai sendi (pilar) pengetahuan, yakni: belajar mengetahui, belajar berbuat, belajar hidup bersama, dan belajar menjadi seseorang (Delors, 1999).

Pertama belajar mengetahui (learning to know), ini bukanlah jenis belajar memperoleh informasi yang sudah dimodifikasi, dirinci, melainkan menguasai instrumen-instrumen pengetahuan ini memampukan setiap orang untuk memahami sedikitnya tentang lingkungan untuk dapat hidup dalam harkatnya, untuk mengembangkan kecakapan kerja, dan untuk berkomunikasi (di samping juga mendasari kegemaran untuk memahami, mengetahui, dan menemukan). Oleh karena itu penting bagi semua orang dimanapun mereka berada untuk mampu memperoleh pengetahuan tentang metode ilmiah, metode belajar bagaimana belajar, mengetahui cara untuk dapat mengetahui, sehingga ia bisa mengetahui tentang sesuatu yang ia perlukan untuk dapat mengetahui, sehingga setiap saat bertambah pengetahuannya.

Pendidikan formal dalam pandangan masa depan, tak memadai lagi menyediakan sejumlah pengetahuan bagi siswa / mahasiswa untuk digunakan sebagai bekal hidup selanjutnya. Pertumbuhan pengetahuan yang demikian masif dengan perubahan begitu cepat, tak mampu lagi dikejar oleh institusi pendidikan yang bertumpu pada paradigma "pembekalan" sejumlah banyak pengetahuan bagi siswa / mahasiswa. Oleh karena itu, jauh lebih penting dari pada belajar tentang susunan pengetahuan adalah belajar instrumen-instrumen pengetahuan itu sendiri.

Kedua belajar berbuat (learning to do) adalah jenis belajar yang tidak terlepas dengan jenis belajar mengetahui. Jenis belajar ini tidak sesederhana konsep tradisional dengan mengajar siswa / mahasiswa untuk mempraktikkan apa yang sudah dipelajari dalam rangka mempersiapkan seseorang untuk tugas praktis perbuatan sesuatu, akan tetapi lebih merupakan representasi belajar kecakapan hidup (suatu kecakapan yang memadukan sejumlah unsur keterampilan kognitif, teknikal, dan sikap). Belajar berbuat tidak dapat dipandang sebagai transmisi sederhana keterampilan-keterampilan diskret.

Ketiga belajar hidup bersama (learning to live together) merupakan antesis dari berbagai bentuk kompetisi, persaingan, perselisihan, pertengkaran, dan peperangan dalam berbagai sektor kehidupan, misalnya sektor politik, ekonomi, budaya, dan agama. Semangat yang dibangun adalah semangat perdamaian, kebersamaan, keselarasan, dan keserasian berkehidupan melalui usaha-usaha atau kerja kolaboratif untuk mencapai tujuan bersama, dan bukan membangun semangat kompetisi dan rivalisasi. Oleh karena itu kata kunci yang ditawarkan adalah sinergi dan kolaborasi. Bahwa kemampuan untuk bersinergi dan berkolaborasi merupakan modal seseorang untuk sukses di masa depan.

Keempat belajar menjadi seseorang (learning to be) merupakan tujuan akhir dari proses pembelajaran setelah orang belajar mengetahui, belajar berbuat dan belajar hidup bersama. Jenis belajar ini bertumpu pada asumsi bahwa manusia 
belajar bagi dirinya sendiri untuk pemenuhan perkembangan seutuhnya setiap manusia, meliputi: jiwa dan raga, intelegensi, kepekaan, tanggung jawab pribadi, dan nilai-nilai spiritual.

Memperhatikan karakteristik keempat pilar belajar tersebut, tampak jelas bahwa keempatnya merupakan proses, dan bukan entitas isi. Oleh karena itu sejumlah pakar ilmu pendidikan beberapa tahun lalu "berteriak" lantang bahwa pendidikan masa depan hendaknya memandang kurikulum bukan lagi sebagai sekumpulan materi pengetahuan, atau seperangkat keterampilan teknis diskret tentang cara menbuat sesuatu, akan tetapi, kurikulum hendaknya dipandang secara lebih luas sebagai wahana belajar untuk membangun instrumen-instrumen pengetahuan, mengembangkan kompetensi, mengembangkan kepekaan sosial, dan membangun kepribadian yang utuh.

Mereka juga menyarankan adanya perubahan orientasi kurikulum, dari kurikulum berbasis isi ke kerikulum kompetensi; atau dari orientasi materialsiasi kurikulum berubah ke dematerialisasi kurikulum. Implikasinya pembelajaran bukanlah penerusan isi materi kurikulum akan tetapi pengembangan kompetensi di atas materi kurikulum.

\section{b. Konsep Kurikulum Berbasis Kompetensi}

KBK adalah seperangkat perencanaan dan pengaturan pembelajaran yang sistematis guna mencapai kompetensi tertentu. Dapat juga dikatakan bahwa KBK merupakan kurikulum yang berisi sejumlah kompetensi yang dibutuhkan dan perlu dikuasai oleh pembelajar untuk menjalani kehidupan mereka, baik untuk mendapatkan pekerjaan, bekerja, melanjutkan studi, maupun belajar sepanjang hayat. Kompetensi tersebut disusun dan dikemas sedemikian rupa sehingga memungkinkan untuk dicapai dan dikuasai oleh pembelajar (siswa / mahasiswa).

Baik dalam tataran formal maupun operasional di lapangan, KBK semestinya memiliki karakteristik umum, yakni:

1) Berbasis kompetensi dasar, bukan berbasis isi atau materi;

2) Bertumpu pada pembentukan kemampuan yang diperlukan oleh siswa/mahasiswa, bukan penerusan materi belajar;

3) Berpendekatan atau berpusat pembelajaran, bukan pengajaran;

4) Berorientasi pada pemerolehan pengalaman belajar siswa / mahasiswa yang kaya, bukan perolehan pengetahuan semata;

5) Berpendekatan terpadu dan integratif, bukan diskret-analisis yang terpisah;

6) Mengutamakan kebermaknaan, keorisinilan, dan keontetikan proses pembelajaran;

7) Bermuatan multi-kecerdasan, multi-strategi;

8) Menggunakan asas maju berkelanjutan dan belajar tuntas;

9) Berpusat pada siswa / mahasiswa, yang berati bahwa siswa / mahasiswa menjadi subyek utama dalam pembelajaran, dan guru / dosen menjadi fasilitator, pendamping, dan sesama pembelajar;

10) Memberikan pengalaman belajar yang relevan dan kontekstual;

11) Membentuk mental yang mantap dan kaya akan pembelajaran;

12) Bersifat diversifikatif, pluralistik, dan multikultural. 


\section{c. Implementasi Kurikulum Berbasis Kompetensi Versi Depdiknas (Kasus di Perguruan Tinggi Indonesia)}

Untuk perguruan tinggi, kehendak kurikulum nasional Tahun 2002 untuk mengembangkan pendidikan sesungguhnya ingin bertumpu pada empat pilar UNESCO. Penerjemahan 4 pilar tersebut ke dalam kurikulum nasional dituangkan dalam tiga pedoman utama, yakni: peguasaan pengetahuan dan keterampilan, sikap, dan pengenalan sifat pekerjaan terkait (Tabel 1). Akan tetapi ketika sampai pada deskripsi matakuliah dengan menyepadankan empat pilar Unesco dengan kelompok-kelompok matakuliah, maka yang terjadi adalah "materialisasi" kurikulum yang dalam hal ini justru menjadi antitesis empat pilar belajar Unesco.

Kurikulum nasional Tahun 2002 (untuk perguruan tinggi), belajar mengetahui disepadankan dengan sekelompok Matakuliah Keilmuan dan Keterampilan (MKK), belajar berbuat disepadankan dengan sekelompok Matakuliah Keahlian Berkarya (MKB), belajar hidup bersama disepadankan dengan sekelompok Matakuliah Berkehidupan Bersama (MBB) dan matakuliah Pengembangan Kepribadian (MPK), dan belajar menjadi seseorang disepadankan dengan sekelompok Matakuliah Perilaku Berkarya (MKB).

Penerjemaahn pilar Unesco menjadi muatan sekelompok matakuliah ini tidak lain merupakan bentuk materialisasi kurikulum, sehingga kurikulum nasional masih dikesani banyak orang sebagai kurikulum berbasis isi.

Tabel 1 Kesepadanan Empat Pilar Unesco dengan Konstruk Kurikulum Nasional (Kasus di Perguruan Tinggi)

\begin{tabular}{|c|c|c|}
\hline Kurikulum Nasional & Unesco & Pengelompokan Matakuliah \\
\hline \multirow{2}{*}{$\begin{array}{l}\text { Penguasaan Pengetahuan dan } \\
\text { Keterampilan } \\
\text { - } \quad \text { Analisis dan sintesis } \\
\text { - } \quad \text { Computing/using IT } \\
\text { - } \quad \text { Manage ambiguity } \\
\text { - } \quad \text { Communication } \\
\text { - } \quad \text { Language }\end{array}$} & Belajar mengetahui & $\begin{array}{l}\text { Matakuliah Keilmuan dan } \\
\text { Keterampilan (MKK) }\end{array}$ \\
\hline & Belajar berbuat & $\begin{array}{l}\text { Matakuliah Keahlian Berkarya } \\
(\mathrm{MKB})\end{array}$ \\
\hline $\begin{array}{l}\text { Pengenalan sifat pekerjaan } \\
\text { terkait: } \\
\text { - } \quad \text { Terlatih dalam etika kerja } \\
\text { - } \quad \text { Memahami makna } \\
\text { globalisasi } \\
\text { - } \quad \text { Fleksibel terhadap pilihan } \\
\text { pekerjaan }\end{array}$ & Belajar hidup bersama & $\begin{array}{l}\text { Matakuliah Berkehidupan } \\
\text { Bersama (MBB) }\end{array}$ \\
\hline \multirow{2}{*}{$\begin{array}{l}\text { Sikap: } \\
\text { - } \quad \text { Kepemimpinan } \\
\text { - } \quad \text { Teamwork } \\
\text { - } \quad \text { Can work crossculturally } \\
\end{array}$} & Belajar menjadi seseorang & $\begin{array}{l}\text { Matakuliah Perilaku Berkarya } \\
\text { (MKB) }\end{array}$ \\
\hline & & $\begin{array}{l}\text { Matakuliah Pengembangan } \\
\text { Kepribadian (MPK) }\end{array}$ \\
\hline
\end{tabular}

Diskursus yang terjadi dikalangan para ahli ilmu pendidikan adalah bahwa: belajar mengetahui, belajar berbuat, belajar hidup bersama, dan belajar menjadi seseorang dalam pandangan Unesco merupakan siklus belajar. Proses belajar ini bisa melekat dalam proses pembelajaran setiap pelajaran / matakuliah, tidak hanya sekelompok mata pelajaran / mata kuliah dengan hanya ditujukan 
untuk satu jenis belajar tertentu. Dengan perkataan lain, dalam pembelajaran suatu mata pelajaran / mata kuliah dapat dikembangkan belajar mengetahui, belajar melakukan, belajar hidup bersama, dan belajar menjadi seseorang sekaligus sebagai suatu siklus belajar. Akan tetapi kurnas menerjemahkan secara berbeda. Satu pilar belajar mewujud pada kelompok mata kuliah tertentu, sehingga berangkat dari empat pilar itu akhirnya dikembangkan menjadi empat kelompok mata kuliah (dalam kasus pengelompokan mata kuliah di perguruan tinggi).

Pro dan kontra terhadap fenomena ini pernah mengemuka pada tahun 2003 s.d. 2004; namun sejauh ini, kurikulum nasional yang tetap menjadi acuan dari implementasi KBK Perguruan Tinggi di Indonesia. Pada kesempatan ini, segenap tenaga fungsional kependidikan (Guru dan Dosen) dan juga sebagai pengelola lembaga pendidikan dihadapkan pada dua pilihan: mengimplementasikan KBK atau tidak. Jika pilihan jatuh pada alternatif yang pertama, yakni mengimplementasikan KBK, maka terdapat sejumlah konsekuensi yang harus dilakukan, sebagai implikasinya.

\section{d. Implikasi Pemberlakuan Kurikulum Berbasis Kompetensi}

Implikasi dari pemberlakuan KBK cukup luas, terutama yang menyangkut proses pembelajaran, diantaranya adalah : pembaharuan pada lingkungan belajar, metode pembelajaran, media belajar, bahan belajar, dan sebagainya. Semua itu menuntut adanya guru / dosen yang juga berbasis kompetensi. Belajar merupakan kegiatan aktif siswa / mahasiswa dalam membangun makna atau pemahaman. Dengan demikian guru/dosen perlu memberikan dorongan kepada siswa / mahasiswa untuk mengunakan otoritasnya dalam membangun gagasan. Tanggung jawab belajar ada pada siswa/mahasiswa, tetapi guru / dosen bertanggung jawab untuk menciptakan situasi yang mendorong prakarsa, motivasi, dan tanggung jawab untuk belajar sepanjang hayat para anak didiknya.

Berdasarkan hal tersebut guru / dosen perlu merancang materi, metode, media, dan model penilaian sebagai "hidangan nikmat" begi siswa/mahasiswa dengan sebuah pendekatan belajar yang lebih memberdayakan dan melayani semua siswa/mahasiswa. Dengan merujuk pada kompetensi dasar dan indikator pencapaian hasil belajar, guru / dosen menciptakan situasi pembelajaran yang memberi peluang bagi siswa/mahasiswa untuk belajar melalui kegiatan "mengalami sendiri" dalam lingkuangan yang alamiah. Oleh karena itu perinsip kegiatan pembelajaran KBK, adalah:

1) Berpusat pada siswa / mahasiswa;

2) Belajar dengan berbuat dan melakukan;

3) Menciptakan suasana belajar yang menyenangkan dan menantang;

4) Mengembangkan beragam kemampuan yang bermuatan nilai;

5) Mengembangkan kemampuan sosial;

6) Mengembangkan keingintahuan, imajinasi, dan fitrah ber-Tuhan;

7) Mengembangakan keterampilan memecahkan masalah;

8) Mengembangkan kreativitas siswa/mahasiswa;

9) Mengembangkan kemampuan menggunakan ilmu dan teknologi;

10) Menumbuhkan kesadaran sebagai warga negara yang baik;

11) Belajar sepanjang hayat; 
12) Membangun kemampuan bersinergi dan berkolaborasi.

Letak perbedaan KBK dengan kurikulum (berbasis isi) sebelumnya, adalah pemusatan perhatian pada perangkat kemampuan lulusan yang dikehendaki, dan bukan pada pengelaran materi dan penerusan materi. Ini berarti bahwa penjabaran atau analisis materi dilakukan berdasarkan rumusan kompetensi yang dikehendaki. Dalam pengejawantahannya, dalam bentuk pengembangan kurikulum intruksional, guru / dosen perlu mengembangkan peta kompetensi dari setiap rumusan kompetensi yang ada di dalam kurikulum formal berbasis kompetensi itu. Pengembangan peta kompetensi ini akan menghasilkan deskripsi yang cermat broad-skill dan sub-skill, dan dari sub-skill ini dapat ditemukan jabaran secara cermat keterampilan kognitif dan teknikal (praktis), sehingga materi (content of subject matter) dapat ditetapkan dan kemudian ditata. Hasil telaah pada kompetensi dapat diorganisasi dalam bentuk ilustrasi Gambar 3.

\begin{tabular}{|c|c|c|c|}
\hline \multicolumn{4}{|c|}{$\begin{array}{l}\text { Statemen Kompetensi } \\
\text { (1) }\end{array}$} \\
\hline Broad-skills & $\begin{array}{l}\text { Keterampilan } \\
\text { Teknikal/Praktik }\end{array}$ & Keterampilan & Isi (Materi) \\
\hline Sub-skill & $\longrightarrow$ & 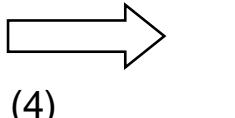 & $(5)$ \\
\hline
\end{tabular}

\section{Gambar 3 Telaah Kompetensi}

Jabaran ini akan membantu dalam membuat skenario pembelajaran secara menyeluruh. Anak panah (2) ke (3) menunjukkan bahwa sub-skills memberikan memberikan indikator-indikator tipe keterampilan teknikal / praktik. Dengan demikian keterampilan teknik / praktik berfungsi sebagai motor (penggerak) untuk mengembangkan sub-skill / broad-skills. Anak panah (3) ke (4) juga menunjukkan bahwa keterampilan kognitif difungsikan sebagai prasyarat pembentukan keterampilan teknikal / praktis; dan keterampilan kognitif dibentuk oleh seperangkat isi yang disusun dan diorganisasi dalam bentuk bahan belajar.

\section{PENUTUP}

Ketika lembaga fungsional kependidikan (dimana pun kita menjadi tenaga guru / dosen) memutuskan untuk mengimplementasikan KBK, maka hendaknya kita cerdas dan arif dalam mengimplementasikannya, setidaknya dengan: belajar segala sesuatu yang berkaitan dengan implementasi KBK, untuk kemudian mengadaptasikannya dalam pelaksanaan di lapangan. Perlu ditegaskan di sini bahwa Undang-undang Guru dan Dosen bertujuan untuk memperbaiki pendidikan nasional, baik secara kualitas maupun kuantitas, agar sumber daya manusia Indonesia bisa lebih bertanggung jawab, dalam arti kata kreatif, inovatif, produktif serta berilmu pengetahuan luas demi meningkatkan kesejahteraan seluruh bangsa.

Sebagaimana diamanatkan UUD 1945 pasal 31 ayat (3) yang menyatakan: pemerintah mengusahakan dan menyelenggarakan satu sistem pendidikan nasional yang meningkatkan keimanan dan ketakwaan serta akhlak mulia dalam 
rangka mencerdaskan kehidupan bangsa. Dan ayat (5) yang menyatakan: pemerintah memajukan ilmu pengetahuan dan teknologi dengan menjunjung tinggi nilai-nilai agama dan persatuan bangsa untuk kemajuan peradapan serta kesejahteraan umat manusia. Kemudian jika dalam proses implementasi ditemukan kejanggalan-kejanggalan (hal-hal yang bertentangan dengan semangat perjuangan pendidikan masa depan bangsa, maka guru, dosen, secara perorangan dan atau kelompok bisa mengajukan judicial review ke Mahkamah Konstitusi. 


\section{DAFTAR PUSTAKA}

Depdiknas. 2002. Implementasi KBK. Jakarta: Depdiknas.

Hariati, E. 2006. Seminar Pendidikan: Menuju Indonesia Masa Depan: Balit Bangda Nganjuk.

Kuartolo. 2002. Inti dari Kurikulum. Jogjakarta.

Kuartolo. 2006. Pendidikan Berbasis Kompetensi. Jogjakarta.

Masome, H. A. H. 2006. Komisi X DPR RI; Mendeteksi Persoalan dan Mencari Solusinya. Jombang: Yayasan Roushon Fikri. 